\title{
Peran Bumdes Dalam Meningkatkan Pertumbuhan Ekonomi Pedesaan Melalui Penguatan Sumber Daya Manusia
}

\author{
Zulifah Chikmawati \\ Universitas Nahdlotul Ulama Sidoarjo \\ hikmawatizulifah@gmail.com
}

\begin{abstract}
The rural economy is still an obstacle in the lives of villagers. Paradigm built in rural communities is poverty, deterioration, backwardness, and various forms of discrimination against the development and growth in rural communities. The most fundamental aspect is the inability of rural communities to manage, develop, and optimize the potential of local and village resources to improve the welfare of the community. Public welfare a major goal in the various aspects of life of the nation. Various programs have been carried out by the government in order to develop and build the local economy with a variety of perspectives and methods. Improve the economy of rural communities in Act 6 of 2014 About the Village provides an option that is expected to form a government village BUMDes (village-owned enterprises). BUMDes provide the widest possible space for the village government to regulate independent local potential and innovation with various facilities provided by the government ole much as 1.4 Billion funding for rural development effectively and efficiently, including infrastructure, education, economy, and programs for welfare for villagers to develop into a concrete and comprehensive. BUMDes optimization by building trust to the community through active participation in parallel that can be done together. BUMDes accommodate all local potential yield components to be managed and developed into a superior product as the process of economic development of society. Excellent products developed through BUMDes can be marketed nationally and internationally in order to improve the quality of the local potential. Therefore, BUMDes will be central to the economy of rural communities to national development. Nation building should start from the development of the village as the spearhead of government. Back to the village to build a village for the better.
\end{abstract}

Keywords: village-owned enterprises, human resources, welfare, economic

\section{PENDAHULUAN}

Perspektif terhadap masyarakat desa menjadi kendala utama dalam pembangunan perdesaan. Mind set terhadap masyarakat terhadap perdesaan menjadi momok tersendiri dikalangan masyarakat awam. Bahwa masyarakat desa adalah masyarakat yang terbelakang serta lambannya pembangunan. Hal ini berimplikasi terhadap kehidupan ekonominya.

Ekonomi perdesaan menjadi dikotomi masyarakat perkotaan. Indikator utamanya adalah pembangunan desa yang tidak semakin berkembang. Terutama pembangunan ekonominya yang monoton dalam kehidupan masyarakat 
perdesaan. Menurut Prof. Maryunani yang disampaikan pada rapat Senat Universitas Brawijaya tanggal 22 Oktober 2007, bahwa secara praktis dan teoritis pembangunan ekonomi harus mengarah secara langsung kepada masyarakat sebagai obyek utama dalam kemajuan ekonomi.

Ekonomi pedesaan menjadi sentra utama untuk meningkatkan kemajuan pembangunan desa. Ada berbagai persoalan dalam pembangunan perdesaan antara lain: perbatasan desa, akses jalan, keamanan, sarana kesehatan, pertanian, komunikasi, pendidikan dan sosial kemasyarakatan (Tim KKN PPMD Unpad, 2014. http://kknm.unpad.ac.id/pamulihan/about/kajian-permasalahan-desapamulihan/. Diakses tanggal 20 september 2015

\section{PEMBAHASAN}

\section{A. Pengertian desa}

Desa dalam pengertian umum menurut mendia UNAND adalah sebagai suatu gejala yang bersifat universal, terdapat dimana pun di dunia ini, sebagai suatu komunitas kecil, yang terikat pada lokalitas tertentu baik seb agai tempat tinggal (secara menetap) maupun bagi pemenuhan kebutuhannya, dan yang terutama yang tergantung pada sektor pertanian (fisip.unand.ac.id).

Pengertian Desa secara umum lebih sering dikaitkan dengan pertanian. Misalnya, Egon E. Bergel (1955: 121), mendefinisikan desa sebagai "setiap pemukiman para petani (peasants)". Sebenarnya, faktor pertanian bukanlah ciri yang harus melekat pada setiap desa. Ciri utama yang terlekat pada setiap desa adalah fungsinya sebagai tempat tinggal (menetap) dari suatu kelompok masyarakat yang relatif kecil.

Landis (eprints.uny.ac.id) terdapat tiga definisi tentang desa yaitu pertama desa itu lingkungan yang penduduknya kurang dari 2.500 orang, kedua desa adalah suatu lingkungan yang penduduknya mempunyai hubungan yang saling akrab serba informal satu sama lain, dan yang ketiga desa adalah suatu lingkungan yang penduduknya hidup dari pertanian Menurut UU no 22 tahun 1999 (file.upi.edu) tentang pemerintah daerah pasal I yang dimaksud dengan desa adalah kesatuan masyarakat hukum yang memiliki kewenangan untuk mngatur dan mengurus kepentingan masyarakat setempat berdasarkan asal-usul dan adat istiadat setempat yang diakui dalam sistem pemerintahan nasional dan berada di daerah kabupaten

Serta menurut UU no 6 tahun 2014 pasal 1 tentang desa menjelaskan bahwa Desa adalah desa dan desa adat atau yang disebut dengan nama lain, selanjutnya disebut Desa, adalah kesatuan masyarakat hukum yang memiliki batas wilayah yang berwenang untuk mengatur dan mengurus urusan pemerintahan, kepentingan masyarakat setempat berdasarkan prakarsa masyarakat, hak asal usul, dan/atau hak tradisional yang diakui dan dihormati dalam sistem pemerintahan Negara Kesatuan Republik Indonesia. 
R.Bintarto (1983:11) menjelaskan desa ialah "suatu hasil perpaduan antara kegiatan sekelompok manusia dengan lingkungannya. Hasil dari perpaduan itu ialah sautu wujud atau kenampakan di muka bumi yang ditimbulkan oleh unsurunsur fisiografi, sosial, ekonomi, politik dan cultural yang saling berinteraksi antar unsur tersebut dan juga dalam hubungannya dengan daerah-daerah lain"

Sementara itu dalam media UNAND pengertian desa menurut Koentjaraningrat (1977) ialah melalui pemilahan pengertian komunitas dalam dua jenis, yaitu komunitas besar (seperti: kota, negara bagian, negara) dan komunitas kecil (seperti: band, desa, rukun tetangga dan sebagainya). Dalam hal ini Koentjaraningrat mendefinisikan desa sebagai "komunitas kecil yang menetap tetap di suatu tempat" (1977:162). Koentjaraningrat tidak memberikan penegasan bahwa komunitas desa secara khusus tergantung pada sektor pertanian. Dengan kata lain artinya bahwa masyarakat desa sebagai sebuah komunitas kecil itu dapat saja memiliki ciri-ciri aktivitas ekonomi yang beragam, tidak di sektor pertanian saja.

Selanjutnya, menurut Paul H. Landis (1948:12-13), seorang sarjana sosiologi perdesaan dari Amerika Serikat, mengemukakan definisi tentang desa dengan cara membuat tiga pemilahan berdasarkan pada tujuan analisis. Untuk tujuan analisis statistik, desa didefinisikan sebagai suatu lingkungan yang penduduknya kurang dari 2500 orang. Untuk tujuan analisa sosial-psikologi, desa didefinisikan sebagai suatu lingkungan yang penduduknya memiliki hubungan yang akrab dan serba informal di antara sesama warganya. Sedangkan untuk tujuan analisa ekonomi, desa didefinisikan sebagai suatu lingkungan yang penduduknya tergantung kepada pertanian (fisip.unand.ac.id, 2013).

Menurut kompasiana desa adalah suatu kesatuan hukum dimana bertempat tinggal suatu masyarakat pemerintahan tersendiri, atau desa merupakan perwujudan atau kesatuan goegrafi ,sosial, ekonomi, politik dan kultur yang terdapat ditempat itu (suatu daerah), dalam hubungan dan pengaruhnya secara timbal balik dengan daerah lain. Suatu pedesaan masih sulit umtuk berkembang, bukannya mereka tidak mau berkembang tapi suatu hal yang baru terkadang bertentangan dengan apa yang leluhur hereka ajarkan karna itu masyarakat pedasaan sangat tertutup dengan hal-hal yang baru karena mereka masih memegang teguh adat-adat yang leluhur mereka ajarkan. Disuatu desa sangat terjangkau fasilitas seperti rumah sakit, sekolah, apotik atau prasarana dlm hal pendidikan dan kesehatan maupun teknologi mereka masih mengandalkan dukun atau paranormal dlm hal kesehatan mungkin hanya puskesmas yang ada di desa tapi itupun belum tentu ada di setiap daerah. Maupun pendidikan masih kurangnya sarana pendidikan didesa didlm sutu kecamatan terkadang hanya satu atau dua sekolahan saja, karena susahnya bantuan masuk dari pemerintah untuk membangun sekolah-sekolah di daerah desa dan terkadang jarang guru yang mau mengajar di daerah pedesaan (www.kompasiana.com, 2011). 
Dengan demikian penegrtian desa jelas memberi gambaran suatu kelompok manusia atau masyarakat yang aktivitasnya berkaitan dengan elemen lingkungan alam atau lingkungan fisik maupun sosial kemasyarakatan, dan memiliki komunikasi dengan daerah lain, secara lancer dan terbuka dan kurang lancer atau terisolir dari dan dengan daerah lain. Ciri-Ciri Perekonomian Desa Menurut kompasiana cirri yang menonjol pada masyarakat pedesaan yaitu :

1. Kehidupan didesa masyarakatnya masih memegang teguh keagamaan atau adat dari leluhur mereka.

2. Warga pedesaan lebih condong saling tolong-menolong tidak hidup individualisme

3. Warga pedesaan mayoritas memiliki pekerjaan sebagai petani.

4. Fasilitas-fasilitas masih sulit ditemukan dipedesaan

5. Warganya masih sulit untuk menerima hal baru atau mereka tertutup dengan hal-hal yang baru

C. Struktur Perekonomian Desa

Sebagai masyarakat pedesaan, sudah barang tentu dengan segala kearifannya masyarakat selalu memanfaatkan seoptimal mungkin potensi almnya, mulai dari bertami, berkebun, berternak dan industri bata. Ketergentungan mereka terhadap lahan sangat kental nuansa ekonomi maupun sosialnya. Sacara ekonomis, lahan dapat menjadi sumber kehidupan ekonomi keluarga selain itu, mereka juga melakukan aktivitas penunjang atau usaha sambilan yang diposisikan sebagai bentuk memenuhi kepentingan makan. Menurut tradisi masyarakat berternak sebenranya tidak hanya menjadi bagian untuk meunjang ekonomi keluarga, tetapi juga bisa menjadi bentuk investasi keluarga, yang bisa di gunakan untuk biaya mendirikan rumah, pernikahan, atau pendidikan anak.

Dengan cara produksi dan pendapatan ekonomi keluarga, dapat diketahui bahwa lapangan kerja masyarakat masih relatif homogen. Dalam hubungan ini, norma-norma dan tradisi yang mengatur pengolahan lahan diharapkan bida arif dan bijaksana, karena fungsi lahan juga mengandung nilai-nilai sosial yang perlu dikembngkan jika komunitas ini butuh perkembangannya.

D. Perekonomian Masyarakat Desa

Ketimpangan pertumbuhan penduduk kawasan pedesaan dan perkotaan yang terjadi akhir-akhir iniperlu diamati dengan cermat. Karena apabila tidak di antisipasi secara dini akan dapat menimbulkan permasalahan yang rumit dan berkepanjangan, khususnya di bidang sosial. Pembangunan desa yang cukup berhasil khusunya dalam program permasyarakatan keluarga berencana ataupun karena fasilitas desa yang bertambah sehingga mampu mengubah status dari desadesa menjadi kota-desa. Tapi apabila hal tersebut di akibatkan karena arus urbanisasi semata maka akan menjadi sebuah permasalahan didesa. Menurut klasifikasi sosial-budaya yang di seluruh Indoensia terdiri dari kurang lebih 5000 jenis bahasa daerah, sehingga tampaknya dari segi bahasa sangat heterogen. 
Namun, bila kita amati lebih dalam ternyata cenderung adanya homogenitas masyarakat pedesaaan. Kenampakannya lebih cenderung ke arah memegang teguh tradisi, mantapnya etnosentrisme masyarakat kawasan pedesaan.

Ekonomi Subsistensi. Berbeda dengan pedesaan di Negara-megara Eropa, Amerika, maupun Australia, penduduk pedesaan Indonesia lebih menyakini keterbukaan ada para pendatang, lebih bersahabat, dan lebih murah senyum. Bahkan nilai-nilai komerialisme tidak tampak, yang menonjol nilai gotong-royong (Hasan, Zaini \& Salladin, 1996: 251).

Adapun yang dimaksud dengan gotong-royong menurut Koentjaraningrat sebagi berikut “.... dalam kehidupan masyarakat desa di Jawa, gotong-royong merupakan suatu system pengnerahan tenaga tambahan dari luar kalangan keluarga, untuk mengisi kekurangan tenaga pada masa-masa sibuk dalam lingkaran aktivitas produksi bercoccok tanam di sawa" (Bintarto, 1980:9)

Untuk keperluan itu seseorang meinta dengan adat sopan santun kepada beberapa orang lain sedesanya untuk membantunya dalam hal bertani maupun kegiatan lain di luar pertanian, tanpa memungut biaya, namun petani tersebut harus berkewajiban untuk membantu apabila yang dimintai tolong saat ini ganti membutuhkannya (salladien, 1989:3 ( melalui Hasan, Zaini \& Salladin, 1996: 251)). Seiring berkembangnya zaman barter tenaga sekarang berganti menggunakan upah.

Gotong royong juga sering dikatakan pula sebagai ekonomi subsitensi Indonesia yang mengakar dengan tujuan barter tenaga yang disertai cita-cita luhur demi kesejahteraan dan kebersamaan penduduk desa. Ekonomi subsitensi mengandung makna hemat bagi para penduduk desa yang umunya bertani, menjauhkan diri dari sikap konsumtif yang mencolok dan kurang hemat, seperti kebnayakan penduduk kota.

Hal ini di tunjang oleh harkat keterpandangan suatu keluarga di desa yang sangat di tentukan oleh keberhasilan membina ketenangan keluarga, luas tanah pertanian, banyaknya ternak, kendaraan yang digunakan kerja harta warisan, dan kesemuanya dapat dilihat dengan mata serta berjangka guna dalam waktu relative panjang. Sehingga dapat dikatakan system ekonomi subssitensi berlawanan dengan ekonomi pasar yang merupakan dasar pola konsumtif masyarakat kota. Walaupun akhir-akhir ini dikembangkan pola keterbukaan informasi yang menelusup di berbagai segi kehidupan, pola ekonomi subsistensi tetap bertahan di kawasan pedesaaan. Terlebih-lebih didesa yang terisolir, pola system subsistensi tetap mendominir (Hasan, Zaini \& Salladin, 1996: 252).

\section{E. Perubahan Perekonomian Desa}

Keterbukaan desa menjadikan desa adalah kepanjangan kota, artinya desa yang terisolir seratus persen hampir tidak ada, hal itu membawa dampak selain 
sosial-budaya yang berubah juga mata pencaharian penduduk yang berubah. Dahulu kala pekerjaan masyarakat desa umunya di bidang usaha sector tradisional, kemudian berubah ke sector formal bagi mereka yang berpendidikan, saat ini menuju ke sector informal, misalnya pedagang kecil tukang becak, tukang ojek, penjaja jasa lainnya (salladien, 1985: 64 (melaui Hasan, Zaini \& Salladin .1996)). Hal tersebut pula oleh kemajuan jalur-jalur transpportasi yang mulus. Dampak lebih jauh adanya keterbukaan desa, mereka berpengharapan pindah ke kota atau urbanisasi akan dapat meningkatkan penghasilan, pendidikan, pekerjaan, keternagakerjaan dan sebagainya apabila tanpa upaya kebijakan yang tepa menyebabkan desa hanya ditinggali oelh mereka yang tua tua, kurang inovatif, kurang terdidik, berpenyakitan, sehingga dapat merugikan desa itu sendiri.

Pada masa lampau usaha di bidang pertanian dapat mencukupi kebutuhan tiap keluarga, pada saat ini penghasilan dari usaha di bidang pertanian kurang mencukupi, karena luas areal pertanian yang tetap sedangkan jumlah penduduk keluarga petani makin bertambah, sehingga luas lahan pertanian perkeluarganya menyempit, dampaknya penghasilan rerarta tiap keluarga petani menurun (salladien 1985:4 (melaui Hasan, Zaini \& Salladin .1996)). Disamping itu Clout 1984:35 (melalui Hasan, Zaini \& Salladin .1996) kebutuhan tiap keluarga meningkat pula, selarasa dengan informasi yang diteriam lewat media-media, misalnya dahulu cukup memiliki sepeda tapi sekarang membutuhkan speeda motor karena jarak tempuh yang jauh, dahulu cukup makan nasi dan garam sekarang makan-makanan yang lain, dan hal itu membutuhkan dana lebih tinggi. Maka berupayalah mereka lewat berbagai kegiatan ekonomi, sehingga akhirnya terjadi ketebukaan ekonomi dan muali meninggalkan system ekonomi subsitensi yang mononton.

E. BUMDes dalam Perspektif UU Desa

Undang-Undang desa mengamahkan dalam pasal 87 bahwa pemerintah desa dapat mendirikan BUMDes; BUMDes harus dibangun dengan semangat kekeluargaan dan kegotongroyongan serta menjalankan usaha di bidang ekonomi atau pelayanan umum untuk kesejahteraan bagi masyarakat desa. BUMDes dibentuk melalui musyawarah desa sebagai bahan pengkajian dan pengambilan keputusan terhadap hal yang dianggap penting dan strategis dalam penyelenggaraan pemerintahan desa sesuai dengan pasal 54 ayat (2a) dan pasal 88 ayat (1).

BUMDes merupakan elemen dan instrument penggerak ekonomi masyarakat desa. BUMDes harus dipahami dan dilakukan secara maksimal. BUMDes menjadi pusat perekonomian masyarakat desa untuk menumbuhkembangkan ekonomi lokal. Keberadaan BUMDes adalah untuk memperkuat ekonomi rakyat desa. (Sutoro Eko, dkk. 2015).

BUMDes menjadi hak desa untuk memanfaatkan aturan UU Desa yang memberikan kewenangan kepada pemerintah desa untuk melakukan inovasi 
dalam pembangunan desa, terutama dalam hal peningkatan perekonomian desa dan kesejahteraan bagi masyarakat desa. BUMDes diharapkan menjadi motor penggerak ekonomi desa masyarakat yang dikelola secara baik dan professional. Keberadaan BUMDes menjadi harapan masyarakat desa untuk meningkatkan ekonomi desa melalui pengelolaan keuangan desa yang di dasarkan pada Anggaran Pembangunan dan Belanja Desa (APBDes). Kawasan Perdesaan memiliki peran yang penting dalam mendukung pembangunan nasional. Kemandirian pembangunan kawasan pedesaan merupakan salah satu pendekatan dalam pembangunan kawasan perdesaan dalam mendorong perkembangan ekonomi di kawasan desa dengan memanfaatkan potensi yang ada di wilayah tersebut. Perkembangan Ekonomi kawasan perdesaan diharapkan dapat mengurangi ketergantungan kawasan pedesaan terhadap kota, dan menguatkanperan desa sebagai pusat produksi dan kebutuhan sumberdaya pembangunan. Membangun hubungan keterkaitan antar desa-kota juga merupakan salah satu cara yang ditempuh sebagai suatu upaya pembangunan wilayah perdesaan, dimana peran desa dikuatkan sebagai pusat produksi dan sumberdaya. Keterkaitan tersebut dapat mengurangi ketergantungan kawasan perdesaan terhadap kawasan perkotaan, dan mengurangi angka urban masyarakat dari desa ke kota. Diharapkan pola tersebut mendorong perkembangan

ekonomi desa dan mendorong permerataan ekonomi antara desa dan kota. Dalam hubungan yang lebih intensif, hubungan desa-kota tersebut dapat berupa interaksi spasial antar subsistem rantai agribisnis/agroindustri (Rustadi, Perkembangan Ekonomi Kawasan Perdesaan

Kawasan Perdesaan memiliki peran yang penting dalam mendukung pembangunan nasional. Kemandirian pembangunan kawasan pedesaan merupakan salah satu pendekatan dalam pembangunan kawasan perdesaan dalam mendorong perkembangan ekonomi di kawasan desa dengan memanfaatkan potensi yang ada di wilayah tersebut. Perkembangan Ekonomi kawasan perdesaan diharapkan dapat mengurangi ketergantungan kawasan pedesaan terhadap kota, dan menguatkan peran desa sebagai pusat produksi dan kebutuhan sumberdaya pembangunan. Membangun hubungan keterkaitan antar desa-kota juga merupakan salah satu cara yang ditempuh sebagai suatu upaya pembangunan wilayah perdesaan, dimana peran desa dikuatkan sebagai pusat produksi dan sumberdaya. Keterkaitan tersebut dapat mengurangi ketergantungan kawasan perdesaan terhadapkawasan perkotaan, dan mengurangi angka urban masyarakat dari desa ke kota. Diharapkan pola tersebut mendorong perkembangan ekonomi desa dan mendorong permerataan ekonomi antara desa dan kota. Dalam hubungan yang lebih intensif, hubungan desa-kota tersebut dapat berupa interaksi spasial antar subsistem rantai agribisnis/agroindustri (Rustadi, 2007).

Dalam mengukur perkembangan ekonomi kawasan perdesaan, Adisasmita (2006) menawarkan beberapa pendekatan. Adapun beberapa 
pendekatan dalam mengukur perkembangan ekonomi kawasan perdesaan adalah sebagai berikut:

\section{1. .Pendapatan Desa Per Kapita}

Pendapatan desa perkapita digunakan sebagai salah satu pendekatan untuk melihat proporsi pendapatan suatu desa terhadap jumlah penduduk desa. Pendapatan desa menggunakan prinsip pendapatan domestik bruto, dihitung dengan jumlah produksi total. Jumlah produksi total tersebut dikonversi dalam nilai total rupiah dan dibagi dengan jumlah pendapatan. Dalam penelitian ini, mengingat variabel pertumbuhan penduduk yang sedikit, maka digunakan pendekatan neraca sumberdaya ekonomi lahan. Sumber Daya Manusia merupakan potensi paling utama dalam pembangunan ekonomi desa. Masyarakat desa yang masih diperspektifkan sebagai masyarakat yang terbelakang harus dibangun berdasarkan pada kemampuan dan kualitas sumber daya manusianya. Pembangunan desa harus dimulai dari pembangunan sumber daya manusianya.

Berbagai persoalan perdesaan dimulai dari kondisi masyarakatnya, sehingga hal itu berimplikasi terhadap potensi sumber daya alam perdesaan, pembangunan perekonomian dan kesejahteraan masyarakatnya. Oleh karena itu penting untuk dikedepankan meningkatkan kualitas sumber daya manusia perdesaan. Pembangunan masyarakat dapat dilakukan melalui pendampingan, penyuluhan, pemberdayaan, dan pendidikan yang berbasis pada penerapan dan implementatif.

2. Pendapatan Masyarakat

Pendapatan masyarakat dalam pendekatan Adisasmita (2006) terkait dengan ketimpangan pendapatan yang terjadi di masyarakat. Dengan kata lain, perkembangan ekonomi perdesaan harus diikuti oleh pemerataan pendapatan di masyarakat. Dalam keadaan ekstrim dimana pendapatan terdistribusi secara merata, 40 persen populasi terbawah akan menerima 40 persen pendapatan, dan 20 persen populasi teratas menerima 40 persen total pendapatan. Dalam penelitian ini, aspek pendapatan dilihat berdasarkan distribusi pendapatan pada masingmasing kelompok penduduk yang terdampak oleh pembangunan infrastruktur karena infrastruktur yang dibangun merupakan infrastruktur dengan pelayanan tersier sehingga diduga tidak memberikan dampak secara menyeluruh terhadap kawasan desa.

\section{3. .Diversifisikasi Ekonomi}

Diversifikasi ekonomi atau perubahan struktur perekonomian daerah perdesaan dilihat berdasarkan perubahan struktur ekonomi perdesaan. Dalam beberapa dekade terakhir, perluasan kawasan perkotaan dan pembukaan akses kawasan perdesaan mengubah struktur ekonomi kawasan perdesaan tidak lagi berat pada sektor pertanian. Hal tersebut tampak pada kawasan-kawasan perdesaan yang mempunyai ciri perkotaan, atau biasa disebut sebagai desa kota. 
Dalam penelitian ini, diversifikasi ekonomi ditilik berdasarkan perubahan struktur mata pencaharian penduduk desa.

APBDes harus menguatkan pada prinsip pembangunan desa dan pemberdayaan kepada masyarakat. Berbagai program dan pembagunan desa seringkali dilakukan oleh pemerintah, tetapi sering gagal dalam proses pendampingan hingga masyarakat benar-benar mandiri. Keberadaan APBDes mempunyai peran dalam proses pembangunan pemerintah desa melalui rencana jangka pendek, menengah maupun panjang. Pembangunan desa sesuai dengan pasal 78 bertujuan untuk meningkatkan kesejahteraan masyarakat desa dan kualitas hidup manusia untuk memenuhi kebutuhan dasar dan menanggulangi kemisikinan, sarana prasarana, pengembangan potensi lokal dan pemanfaatan sumber daya alam dan lingkungan secara berkelanjutan.

Pembangunan desa berkelanjutan menjadi titik sentral dalam pembangunan desa, pelaksanaan MEA (Masyarakat Ekonomi ASEAN) menjadi tantangan pemerintah desa dalam melakukan berbagai inovasi pembangunan. Tantangan dalam dunia global harus dihadapi oleh penguatan terhadap sumber daya manusia desa, infrastruktur dan sistem pemerintahan yang baik dan professional. Perekonomian harus lebih cepat bergerak, inovasi harus terus dilakukan dan dikembangkan, pendampingan kepada masyarakat harus terus diintensifkan untuk membangun sebuah kemandirian bagi desa.

Untuk meningkatkan desa mandiri melalui pembangunan dan pemberdayaan bagi masyarakat desa harus terus dilakukan oleh pemerintah dan daearah sebagai pola pendampingan. Pendampingan terhadap masyarakat desa penting dilakukan sesuai dengan Peraturan Pemerintah Nomor 34 tahun 2014 tentang Desa pasal 28 ayat (1) menjelaskan bahwa pendampingan secara berjenjang harus terus dilakukan sesuai dengan kebutuhan. Pendampingan berjenjang artinya bahwa pendampingan dilakukan secara terus menerus sesuai dengan harapan yang diinginkan oleh masyarakat. Pendampingan terhadap pemberdayaan masyarakat dilakukan secara berjenjang dengan tetap memperhatikan aspek kemandirian masyarakat. Masyarakat yang mandiri mempunyai peran strategis dalam pembangunan desa yang berkelanjutan. Dari pemberdayaan masyarakat akan menghasilkan sumber daya yang potensial dan profesional yang dapat dijadikan sebagai pondasi dasar dalam pembangunan desa yagn berkelanjutan.

Dalam meningkatkan percepatan pembvangunan Desa dapat melalui ; Pembangunan Desa Melalui Peningkatan Sumber DayaManusia

Pemerintah desa sebagai ujung tombak pemerintah pusat dalam sistem pemerintahan mempunyai peran penting dalam meningkatkan pembangunan nasional. Berbagai persoalan pembangunan masih menjadi pekerjaan rumah bagi pemerintah dalam meningkatkan pembangunan secara merata dan sistematis. Banyak kendala yang dihadapi oleh pemerintah pusat dalam peningkatan 
ekonomi, karena semakin ketatnya persaingan ekonomi global dengan berbagai faktor yang mempengaruhinya, inflasi masih menghantui perekonomian nasional, penurunan nilai mata uang terus merangkak dan problematika lainnya yang saling bergesekan, sehingga berpengaruh terhadap perekonomian nasional.

Untuk meningkatkan pembangunan nasional harus dimulai dari bawah, yaitu pembangunan secara bottom up. Pembangunan nasional bisa berhasil jika dilakukan dengan mengintegrasikan pembangunan pedesaan sebagai ujung tombak pemerintah pusat. Melalui UU Desa no 6 tahun 2014, pemerintah sudah menyiapkan berbagai program pendampingan dan pembangunan desa secara menyeluruh. Melalui dana 1, 4 Miliyar yang dicanangkan pemerintah untuk pembangunan desa menjadi angin segar bagi pemerintah desa dalam mengoptimalkan pembangunan desanya.

Diharapkan dengan munculnya UU 6 tahun /2014 dapat memberikan suntinkan semangat dalam meningkatkan ekonomi desa dan kesejahteraan bagi masyarakat desa. Tidak hanya itu, pemerintah pusat juga sudah menyiapkan berbagai instrument lain yang mendukung pembangunan desa secara komprehensif dan totaliter. Pendampingan terhadap pemerintah desa, pengelolaan dana desa, reformasi birokrasi desa, dan peningkatan infrastruktur desa juga menjadi rencana janka panjang dalam pembangunan desa.

Sejatinya, pembangunan desa menjadi motor penggerak bagi pembangunan nasional. Menghadapi MEA (Masyarakat Ekonomi ASEAN) dan AFTA (ASEAN Free Trade Area) Indonesia dituntut harus siap dengan berbagai konskuensinya. Serbuan sumber daya manusia asing dan perdagangan semakin ketat melalui kompetensinya. Membutuhkan kematangan dan kesiapsiagaan dengan membangun pondasi pembangunan secara maksimal.

Desa mempunyai peran utama dalam menghadapi MEA dan AFTA. Pembangunan desa yang meningkat dan perekonomian desa yang semakin baik memberikan implikasi terhadap kemandirian desa. Kemandirian desa sebagai target penting dalam pembangunan desa, sehingga dengan desa yang mandiri memberikan dampak positif terhadap pembangunan sumber daya manusia desa. Peningkatan sumber daya manusia desa mempunyai feed back bagi pembangunn desa yang semakin baik dan berkualitas. Desa yang mandiri yang dikelola oleh sumber daya manusia yang berkualitas memberikan dampak kualitas pada pembangunan desa, meningkatkan kualitas pendidikan masyarakat, meminimalisir migrasi dari desa ke kota, penguatan terhadap kesehatan masyarakat, dan dampak yang diharapkan, yaitu terhadap pembangunan secara nasional.

Word Bank (2004) menyatakan bahwa rendahnya investasi dipengaruhi oleh rendahnya infrastruktur dan sarana dan prasarana publik, sehingga berdampak terhadap pertumbuhan ekonomi dan integrasi ekonomi tidak berjalan dengan baik. (Hayat, 2013). 
Oleh karena itu, untuk meningkatkan pembangunan desa sesuai dengan UU Desa salah satunya adalah dengan melakukan terobosan melalui pembangunan Badan Usaha Milik Desa (BUMDes). BUMDes dirancang untuk meningkatkan ekonomi desa dan kesejahteraan bagi masyarakat desa. BUMDes sebagai lumbung ekonomi desa harus dilakukan secara integrasi antara pemerintah pusat, pemerintah desa dan masyarakat desa. BUMDes bisa saja menjadi sentral ekonomi pedesaan, sehingga dapat menghasilkan produk unggulan desa yang dapat dipasarkan ke dunia international.

Banyak potensi dan sumber daya desa yang tidak teridentifikasi secara baik dan tidak terpetakan secara optimal, sehingga potensi desa hanya menjadi konsumsi penduduk desa tanpa ada nilai yang dapat dikembangkan menjadi sumber peningkatan ekonomi desa. Oleh karena itu, Program kerja pemerintah dengan Nawacita dan Kabinet Kerja, Kerja, dan Kerja dapat dirasakan manfaatnya oleh masyarakat, sehingga kemandirian desa, peningkatan ekonomi, dan kesejahteraan masyarakat desa sudah dapat dinikmati. Pembangunan nasional dikatakan berhasil jika pembangunan desa dan kesejahteraan masyarakat tercapai dengan baik.

Peningkatan Strategi Pembangunan Ekonomi Perdesaan

BUMDes sebagai badan usaha desa sangat berpengaruh terhadap peningkatan kesejahteraan masyarakat. BUMDes sebagai sebuah program yang dirancang oleh pemerintah untuk meningkatkan taraf hidup masyarakat yang lebih baik. Sebagai badan usaha desa tentunya harus dikelola secara bersama untuk kepentingan bersama. BUMDes menjadi sumber usaha masyarakat dalam memaksimalkan potensi yang ada di desa. Pada pembahasan di atas sudah disinggung bahwa BUMDes menjadi pilot project dalam meningkatkan hasil potensi desa menjadi produk unggulan yang dapat menembus pasar international.

Lantas di mana letak peran BUMDes dalam meningkatkan kesejahteraan masyarakat? Peran BUMDes antara lain: (1) identifikasi potensi desa; (2) pemetaan usaha unggulan desa; (3) membangun sentra ekonomi yang terintegrasi; dan (4) memasarkan produk unggulan desa.

Oleh karena ini harus dibangun sebuah strategi pembangunan ekonomi desa dengan melibatkan peran BUMDes di dalamnya sebagai salah satu pilar pembangunan desa yang berkelanjutan.

Willy Wirasasmita berpendapat bahwa untuk meningkatkan ekonomi perdesaan harus dilakukan dengan strategi pembangunan yang berkarakter, yaitu: (1) mempunyai kemampuan dalam menyelesaikan berbagai persoalan di dalam ekonomi perdesaan; (2) memaksimalkan penyelesaian perekonomian tidak harus melakukan peminjaman kepada pihak eksternal dalam menyelesaikan permasalahan perekonomian; (3) memanfaatkan hasil sumber daya pembangunan yang ada dengan memberikan kepastian secara hukum kepada masyarakat dengan mengoptimalkan pelaksanaannya; (4) menjadikan pembangunan terus 
berkelanjutan untuk masyarakat yang lebih baik untuk masa yang akan datang. (http://cibodas.desa.id/strategi-pembangunan-ekonomi-pedesaan/. Diakses tanggal 2 September 2015).

Strategi di atas menjadi pedoman dalam pembangunan ekonomi perdesaan, terutama dalam hal penanganan berbagai persoalan yang muncul dalam kehidupan masyarakat desa. Penting untuk diimplementasikan sebagai sebuah pola peningkatan kesejahteraan masyarakat desa. Berkaitan dengan persoalan ekonomi perdesaan melibatkan seluruh elemen masyarakat dan pemerintahan perdesaan.

Namun demikian, strategi penyelesaian persoalan ekonomi perdesaan tidak cukup, masih dibutuhkan sebuah konsep pembangunan ekonomi perdesaan menjadi lebih baik, antara lain sumber daya manusia, pemberdayaan masyarakat, pengelolaan potensi desa, pertanian berkelanjutan, Peternakan berbasis diversifikasi produk, Pengembangan Kawasan Agropolitan, Pengembangan Agroindustri. (http://cibodas.desa.id/strategi-pembangunanekonomi-pedesaan/. Diakses tanggal 2 September 2015).

Setelah sumber daya manusia mengalami peningkatan, pemberdayaan masyarakat harus ditekankan sebagai prioritas dalam pembangunan. Pemberdayaan masyarakat adalah melakukan motivasi dan support kepada masyarakat untuk bisa mandiri dan berdaya dengan berbagai potensi yang dimilikinya. Masyarakat dapat dikatakan berdaya jika memaksimalkan berbagai potensi yang ada dimasyarakat, baik potensi sumber daya manusia, potensi sumber daya alam dan potensi sumber daya strukturla. Akumulasi dari semua potensi tersebut dapat menciptakan masyarakat yang berdaya. Keberdayaan masyarakat secara otomatis akan mempengaruhi tingkat ekonomi dan kesejahteraannya.

Dewi Atmanti (2005) dalam Hayat (2013) menjelaskan bahwa seseorang dapat meningkatkan penghasilannya melalui peningkatan pendidikan atau kualitas sumber daya manusia. Pendidikan dapat dijadikan sebagai modal utama untuk meningkatkan produktifitas kerja yang berpengaruh dalam kehidupan manusia itu sendiri.

Pemberdayaan potensi desa tidak akan berkembang jika sumber daya manusia dan pemberdayaan tidak dilakukan. Pemberdayaan potensi desa sebagai bahan baku dalam meningkatkan ekonomi perdesaan. Potensi alam harus digali dan dioptimalkan oleh masyarakat desa. Potensi desa yang diidentifikasi secara baik, kemudian dikelola menjadi sesuatu yang lebih berkualitas serta dilakukun oleh sumber daya manusia yang handal, dapat diapstikan pembangunan desa secara berkelanjutan akan dengan sendirinya terbangun. Kesejahteraan dapat dicapai. 
Vol.5 / No.1: 101-113, Januari 2019

ISSN : 2599-3348 (online)

ISSN : 2460-0083 (cetak)

\section{KESIMPULAN}

BUMDes salah satu pilar pembangunan desa yang digalakkan oleh pemerintah untuk meningkatkan kesejahteraan masyarakat pedesaan. Sebagai sebuah sentral ekonomi desa, diharapkan BUMDes mempunyai peran dalam pembangunan desa yang berkelanjutan, pemberdayaan masyarakat desa, dan peningkatan terhadap ekonomi desa.

Ekonomi pedesaan harus dilakukan berdasarkan potensi yang dimiliki. Potensi sumber daya manusia, sumber daya alam, sumber daya infrastruktur dan sumber daya struktur. Persoalan kesejahteraan masyarakat desa bermula dari tingkat ekonomi masyarakat desa yang rendah. Strategi pembangunan desa harus dilakukan secara komprehensip dengan berbagai potensi yang dimilikinya. Kualitas sumber daya manusia desa juga perlu untuk terus ditingkatkan dengan berbagai program dan pendampingan. Goal yang diharapkan adalah terciptanya masyarakat desa yang mandiri, berdaya saing, sejahtera dan berkualitas.

\section{DAFTAR PUSTAKA}

Hayat. (2013). Realokasi Kebijakan Fiskal; Implikasi Peningkatan Human Capital dan Pembangunan Infrastruktur Terhadap Pertumbuhan Ekonomi dan Kesejahteraan Masyarakat. Jurnal Bina Praja, Volume 6 Nomor 2 Tahun 2013.

Maryunani. (2007). Penguatan Perekonomian Desa. http://prasetya.ub.ac.id/berita/Prof-Dr-Maryunani-SE-MS-PenguatanPerekonomian-Desa-7885-id.html. Diakses tanggal 18 Oktober 2015

Peraturan Pemerintah Nomor 43 Tahun 2014 Tentang Desa

Sutoro Eko, dkk. (2015). Modul Pelatihan Pratugas Pendampingan Desa: Implementasi Undang-Undang Desa Nomor 6 Tahun 2014 Tentang Desa. Kementerian Desa, Pembangunan Daerah Tertinggal dan Transmigrasi. Saturday, October 31, 2015 Ekonomi Pedesaan 2007.

Tim KKN PPMD Unpad, (2014). Kajian Permasalahan Desa.http://kknm.unpad.ac.id/pamulihan/about/kajian-permasalahandesa-pamulihan/. Diakses tanggal 20 september 2015

Undang-Undang Nomor 4 Tahun 2014 Tentang Desa

Willy Wirasamita. (2014). Strategi Pembangunan Ekonomi Pedesaan. http://cibodas.desa.id/strategi-pembangunan-ekonomi-pedesaan/. Diakses tanggal 2 September 2015 